\title{
Decreased Libido
}

National Cancer Institute

\section{Source}

National Cancer Institute. Decreased Libido. NCI Thesaurus. Code C78432.

Decreased sexual desire. 